
в России и Беларуси

Е. В. ХРАБРОВА - доцент кафедры уголовно-исполнительного права и организации воспитательной работы с осужденными ВИПЭ ФСИН России, кандидат педагогических наук, доцент;

Д. А. ПАВЛЕНКО - старший инспектор по особым поручениям группы психологического обеспечения управления организации исправительного процесса Департамента исполнения наказаний МВД Республики Беларусь 
Р е ферат

Воспитательная работа с осужденными является средством их исправления, что закреплено в уголовно-исполнительных кодексах Российской Федерации и Республики Беларусь. В настоящее время существуют разнообразные классификации форм данной работы. В УИК РФ закреплены индивидуальные, групповые и массовые формы воспитательной работы с осужденными. Белорусский законодатель не преследует цель урегулировать все формы и методы ее организации, так как данная деятельность носит педагогический характер.

В настоящее время приоритет отдается индивидуальным формам воспитательной работы с несовершеннолетними осужденными в исправительных учреждениях. Вместе с тем огромным потенциалом обладают и групповые формы. Результатом правильно проведенной работы с группой воспитанников может являться коллектив, характеризующийся единством организации и психологической общности. Необходимость использования групповых форм воспитательной работы обусловлена также возрастными особенностями осужденных.

В статье рассматриваются различные формы воспитательной работы, используемые в России и Беларуси, делается акцент на специфических формах, таких как заседания советов коллективов и их секций, подготовка коллективных и индивидуальных трудовых обязательств, конкурсы и слеты передовиков труда и примерного поведения, рационализаторов и изобретателей и др.

К лючевы е слова: воспитательная работа; несовершеннолетний осужденный; воспитательная колония; уголовно-исполнительное законодательство Российской Федерации и Республики Беларусь.

\title{
Organization of group forms of educational work with juvenile convicts in educational colonies in Russia and Belarus
}

\author{
E. V. KHRABROVA - Associate Professor of the Department of Penal Law and \\ Organization of Educational Work with Convicts of the Vologda Institute of Law \\ and Economics of the Federal Penal Service of Russia, PhD. in Law, Associate \\ Professor;
}

D. A. PAVLENKO - Senior Inspector for Special Assignments of the Psychological Support Unit of the Correction Process Organization of the Penal Department of the Ministry of Internal Affairs of the Republic of Belarus

\section{Abstract}

Educational work with convicts is a tool of correcting them, which is enshrined in the penal codes of the Russian Federation and the Republic of Belarus. Currently there are various classifications of this work forms. Individual, group and mass forms of educational work with convicts are enshrined in the Penal Code of RF. The Belarusian legislator does not pursue the goal to regulate all forms and methods of its organization since this activity is of a pedagogical nature.

Currently priority is given to individual forms of educational work with juvenile convicts in correctional institutions. At the same time group forms have enormous potential. The result of a correctly conducted work with a group of pupils may be a team characterized by the unity of the organization and psychological community. The need to use group forms of educational work is also due to the age characteristics of convicts.

The article discusses various forms of educational work used in Russia and Belarus, focuses on specific forms such as meetings of collective councils and their sections, the preparation of collective and individual labor commitments, contests and meetings of the best workers and exemplary behavior, rationalizers and inventors, etc.

Ke y w ord s : educational work; juvenile convict; educational colony; penal legislation of the Russian Federation and the Republic of Belarus.

13.00.01 - General pedagogy, history of pedagogy and education

Воспитательная работа в соответствии с уголовно-исполнительными кодексами Российской Федерации и Республики Беларусь (далее - УИК РФ и УИК РБ [6]) является одним из средств исправления осужденных (ст. 9 УИК РФ и ст. 7 УИК РБ). Статьей 109 УИК РФ установлено, что воспитательная работа с осужденными к лишению свободы 
направлена на их исправление, формирование уважительного отношения к человеку, обществу, труду, нормам и традициям человеческого общежития, повышение их образовательного и культурного уровней. В ст. 104 УИК РБ воспитательная работа с осужденными к лишению свободы понимается как планомерная деятельность работников исправительных учреждений, представителей государственных и общественных организаций, направленная на формирование и укрепление у осужденных стремления к занятию общественно полезной деятельностью, добросовестного отношения к труду, соблюдение требований законодательства и принятых в обществе правил поведения, повышение их культурного уровня.

Воспитательная работа осуществляется в индивидуальных, групповых и массовых формах, что закреплено в УИК РФ. Как отмечает С. В. Казак, белорусский законодатель не преследует цель урегулировать все формы и методы ее организации, поскольку данная деятельность носит педагогический характер. Администрации исправительных учреждений предоставляется право творческого применения наиболее эффективных средств воздействия, если они не противоречат закону [1, с. 210]. В. Г. Стуканов по количеству участников выделяет индивидуальные (сотрудник - осужденный) и групповые (сотрудник - осужденные бригады, отряда, колонии и т. д.) формы воспитательной работы [5, с. 158].

В настоящее время приоритет отдается индивидуальным формам работы, но и групповые формы обладают значительным воспитательным потенциалом.

Группа представляет собой общность людей, находящихся друг с другом в непосредственном психологическом контакте. Результатом правильно проведенной работы с группой воспитанников может являться коллектив, характеризующийся единством организации и психологической общности. В случае отсутствия руководства со стороны сотрудников воспитательной колонии в среде несовершеннолетних начинает процветать криминальная субкультура и формируется антиколлектив (по классификации Л. И. Уманского). Так, А. С. Макаренко писал: «Соберите самых лучших детей, поставьте около них плохих педагогов, и через месяц они разнесут и колонию, и детдом, и школу, и этих педагогов» [2, с. 195].

Необходимость использования групповых форм воспитательной работы обусловлена возрастными особенностями несовершеннолетних осужденных. Период жизни человека от 14 до 18 лет характеризуется социальным, личностным, профессиональным, духовно-практическим самоопределением, которое происходит в различных видах деятельности, в том числе в процессе общения со сверстниками.

Как отмечает В. И. Слободчиков, в сообществе сверстников, где взаимоотношения строятся принципиально на равных началах и статус необходимо заслужить и уметь поддержать, формируются важные для взрослой жизни коммуникативные качества, приобретается жизненный опыт взаимодействия, появляются реалистичные представления о мире и себе. Сознание групповой принадлежности, солидарности, взаимопомощи не только облегчает подростку и юноше обособление от взрослых, но и дает ему чрезвычайно важное чувство эмоционального благополучия и устойчивости [4, с. 308]. Если занятие (участие в кружковой работе, спортивной секции, театральной студии и т. п.) не представляет для него интерес либо его не принимают сверстники, он будет искать возможность самоутвердиться в другой деятельности, в том числе и асоциальной.

В правильно сформированной группе воспитанников складывается система отношений, основанная на общности интересов и потребностей, происходит осознание целей совместной деятельности, создается функционально-ролевая позитивная взаимозависимость, связанная с радостью общения и возможностью достижения успеха в результате совместной деятельности, обеспечивается сочетание индивидуальной оценки деятельности каждого члена в отдельности и группы в целом; неуверенные в себе подростки находят социально-психологическую и эмоциональную поддержку.

Групповые формы воспитательной работы в России и Беларуси реализуются с целью:

- формирования в среде несовершеннолетних осужденных позитивного социально-психологического климата, предупреждения негативных социальных явлений;

- развития организованности и разумной инициативы при выполнении различных видов социально значимой деятельности;

- поддержания среди осужденных дисциплины, предупреждения совершения ими правонарушений;

- рациональной организации досуга осужденных, вовлечения их в процесс самообразования и саморазвития;

- просвещения осужденных в различных отраслях знаний и культуры, расширения их кругозора; 
- создания условий для физического и духовного развития личности осужденных, а также возможностей для достижения ими общественного признания социально приемлемым способом.

В воспитательных колониях Российской Федерации рассматриваемая работы реализуется в таких групповых формах, как социально-правовые занятия (лекции), беседы, общие собрания, диспуты, викторины, кружковая работа, спортивные соревнования, конкурсы профессионального мастерства [3, с. 143-144]. В Республике Беларусь используются и другие виды. Например, заседания советов коллективов и их секций, смотры полезных дел отрядов, подготовка коллективных и индивидуальных трудовых обязательств, конкурсы и слеты передовиков труда и примерного поведения, рационализаторов и изобретателей, выставки самоагитации [5, с. 159], что обусловлено функционированием самодеятельных организаций осужденных.

Интерес представляет используемая в Беларуси классификация групповых форм воспитательной работы, объединенных по цели их использования и содержанию деятельности. Выделяются пять групп, а именно: информационно-разъяснительная работа, организационно обеспечивающая работа, образовательно-просветительская работа, культурно-массовая работа, физкультурно-спортивная работа.

Так, информационно-разъяснительная работа направлена на доведение до осужденных информации, касающейся порядка и условий отбывания наказания, своевременное разъяснение возникающих в связи с этим вопросов. Наиболее эффективны такие формы работы, как беседа с коллективом осужденных и собрание-встреча осужденных с руководством воспитательной колонии.

Беседа с коллективом осужденных представляет собой доведение информации по заранее избранной теме, строящееся в форме диалога с аудиторией и содержащее элементы тематической дискуссии (диспута). Собрание-встреча - это организованный сбор коллектива осужденных руководством воспитательной колонии для обсуждения вопросов дисциплины, правопорядка, трудовой деятельности и иных аспектов жизнедеятельности исправительного учреждения.

Организационно обеспечивающая работа направлена на раскрытие воспитательного потенциала коллективов осужденных (санитарные дни с проведением генеральной уборки всех помещений расположения отряда и закрепленного за отрядом участка территории воспитательной колонии, заседания советов отрядов и его секций). Например, на заседаниях совета отряда и его секций заслушиваются отчеты о проделанной работе, обсуждаются предложения об организации воспитательных и досуговых мероприятий, проводятся собеседования с вновь прибывшими в отряд, с осужденными с негативным поведением в целом.

Целью образовательно-просветительской работы является повышение образовательного, интеллектуального, нравственного и культурного уровня несовершеннолетних осужденных, расширение их кругозора в области права, этики, истории, литературы и в иных сферах знаний и культуры. Организуется образовательно-просветительская работа, как правило, через коллективный просмотр осужденными телепередач, документальных и художественных фильмов с их последующим обсуждением, лекции, тематические дискуссии, викторины, встречи осужденных с представителями государственных и общественных организаций. Так, в отряде в течение месяца проводятся несколько (от 4 до 8) взаимосвязанных лекций в рамках одного направления воспитания (например, курс лекций по нравственному воспитанию «Что такое мораль и нравственность?», «Соотношение норм права и нравственности», «Что такое аморальный поступок?», «К чему приводит аморальное поведение?», «Основные признаки нравственного человека»), которые завершаются тематической дискуссией («Всегда ли нарушение нравственности, аморальный поступок приносят зло?»).

Культурно-массовая работа проводится с целью приобщения осужденных к культуре и искусству через визуальное и эмоциональное восприятие, вовлечение в практическую творческую деятельность. Она организуется посредством проведения выставок (конкурсов) рисунков, конкурсов сочинений, литературных программ, конкурсов поэтического творчества, театральных постановок, музыкальных программ, конкурсов художественной самодеятельности.

Физкультурно-спортивная работа направлена на формирование потребности в регулярных занятиях физической культурой и спортом.

Многие из перечисленных групповых форм работы используются и в воспитательных колониях Российской Федерации. Так, во всех исправительных учреждениях проводятся спортивные соревнования по футболу, волейболу, баскетболу, силовым 
видам спорта и др., функционируют кружки (например, в Тюменской воспитательной колонии УФСИН России по Тюменской области с 2019 г. работает театральный кружок «Сказка», воспитанники Новооскольской воспитательной колонии УФСИН России по Белгородской области ставили спектакль «Женская доля»).

Использование групповых форм воспитательной работы предполагает организацию следующих этапов:

1) создание мотивации для участия в групповых формах воспитательной работы с помощью использования таких методов работы, как лекция (рассказ) об интересных исторических аспектах, известных личностях и др., показ документального или художественного фильма с обязательным обсуждением, приглашение профессиональных спортсменов, актеров и их рассказ о своей жизни, достижениях и др.;

2) определение цели и задач участия осужденных в групповых формах воспитательной работы. Цель должна быть актуальной и доступной;

3) разработка положения об организации групповой формы воспитательной работы (актуально для кружковой работы, спортивных соревнований, соревнований профессионального мастерства и т. п.), которое должно включать программу, цель и задачи проведения, место и сроки, требования к участникам, критерии оценки результатов, меры стимулирования;

4) составление плана на год, где должны быть отражены ближние, средние и дальние перспективы развития несовершеннолетних осужденных;

5) предварительная подготовка (определение даты и места проведения, ответственных за художественное оформление), информационное обеспечение и музыкальное сопровождение;

6) проведение групповой формы воспитательной работы с несовершеннолетними осужденными;

7) анализ проделанной работы (обсуждение с участниками успешности (неуспешности) результата, проектирование более продуктивной деятельности в будущем; психолого-педагогический анализ).

Таким образом, в воспитательной работе с несовершеннолетними осужденными в воспитательных колониях в России и Беларуси широко используются групповые формы. В Республике Беларусь реализуются такие специфические формы, как заседания советов коллективов и их секций, подготовка коллективных и индивидуальных трудовых обязательств, конкурсы и слеты передовиков труда и примерного поведения, рационализаторов и изобретателей, что обусловлено функционированием самодеятельных организаций осужденных.

\section{СПИСОК ЛИТЕРАТУРЫ}

1. Колченогова О. П., Казак С. В., Шарков А. В. Научно-методические основы криминологии и уголовно-исполнительного права : учеб. пособие. Минск, 2014. 349 с.

2. Макаренко А. С. Художественная литература о воспитании несовершеннолетних правонарушителей // Макаренко А. С. Школа жизни, труда, воспитания : в 9 ч. Н. Новгород, 2011. Ч. 5. Статьи, выступления, письма, подготовленные материалы, «Книга для родителей» 1936-1937 гг. С. 191-211.

3. Методические рекомендации по эффективной организации воспитательной работы с осужденными в исправительных учреждениях территориальных органов ФСИН России // Сборник методических рекомендаций ФСИН России. М., 2018. С. 139-157.

4. Слободчиков В. И., Исаев Е. И. Основы психологической антропологии. Психология развития человека. Развитие субъективной реальности в онтогенезе. М., 2000. 416 с.

5. Стуканов В. Г. Исправительная педагогика : учеб. пособие. Минск, 2013. 395 с.

6. Уголовно-исполнительный кодекс Республики Беларусь. URL: http://etalonline.by/document/?regnum=HK0000365 (дата обращения: 15.04.2019).

\section{REFERENCES}

1. Kolchenogova O. P., Kazak S. V., SHarkov A. V. Nauchno-metodicheskie osnovy kriminologii i ugolovno-ispolnitel'nogo prava : ucheb. posobie [Scientific and methodological foundations of criminology and penal law : tutorial]. Minsk, 2014. 349 p. (In Russ.).

2. Makarenko A. S. Hudozhestvennaya literatura o vospitanii nesovershennoletnih pravonarushitelej [Fiction on the education of juvenile offenders]. Makarenko A. S. SHkola zhizni, truda, vospitaniya : v 9 ch. [School of life, labor, education : in 9 parts]. N. Novgorod, 2011. Part 5. Pp. 191-211. (In Russ.).

3. Metodicheskie rekomendacii po effektivnoj organizacii vospitatel'noj raboty s osuzhdennymi $v$ ispravitel'nyh uchrezhdeniyah territorial'nyh organov FSIN Rossii [Guidelines for the effective organization of educational work with convicts in correctional institutions of territorial bodies of the Federal Penal Service of Russia]. Sbornik metodicheskih rekomendacij UVSPR FSIN Rossii - Collection of guidelines for the office of social, educational and psychodogic work of the Federal Penal Service of Russia. Moscow, 2018. Pp. 139-157. (In Russ.).

4. Slobodchikov V. I., Isaev E. I. Osnovy psihologicheskoj antropologii. Psihologiya razvitiya cheloveka. Razvitie sub»ektivnoj real'nosti v ontogeneze [Basics of psychological anthropology. Psychology of human development. The development of subjective reality in ontogenesis]. Moscow, 2000. 416 p. (In Russ.).

5. Stukanov V. G. Ispravitel'naya pedagogika : ucheb. posobie [Correctional pedagogy : tutorial]. Minsk, 2013.395 p. (In Russ.). 6. Ugolovno-ispolnitel'nyj kodeks Respubliki Belarus' [Penal Code of the Republic of Belarus]. Available at: http://etalonline. by/document/?regnum=HK0000365 (accessed 15.04.2019). (In Russ.). 